\title{
両手協応動作の習熟解析
}

○福田康明, 原 盛将（名城大・理工）

\section{Learning Analysis of Both Hands Cooperation Motion}

Yasuaki Fukuta,Shigemasa Hara(Fac.of sic.\&Tech.,Meijo Univ.)

\section{1.はじめに}

近年、製品市場の要求により、各工場では 多品種少量生産が増加している。この生産方 式を作業管理から検討すれば、作業難易が絶 えず変化することにある。この場合、問題と なる要因のひとつに工数見積りの設定があ る。それには作業難易を考慮した作業者の習 熟効果を適切に把握することが重要となる。

本研究では、旋盤作業を模型化した両手協 応動作の習熟実験を行い、作業難易と習熟の 関係について考察した。

\section{2. 達成度の評価理論}

達成度手法は、同一作業や類似作業を連続 的に行う場合、作業時間のばらつきを定量的 に把握し、作業状態を数値的に評価する手法 である。いま、ある作業を連続して繰り返す 場合、最も理想的な作業評価量を 1 とする。 1 回の作業で得られる評価量を $\mathrm{q}(0 \leqq \mathrm{q} \leqq 1)$, 達成されなかった評価量を(1-q), 改善率を $\mathrm{r}$ $(0<\mathrm{r} \leqq 1)$ とし、この作業を $\mathrm{n}$ 回繰り返した時 の作業評価量 Q n は、式(1)で表される。

$$
Q_{n}=q(q-1)^{n-1}+r\left\{\frac{1-(q-r)^{n-1}}{1-(q-r)}\right\}
$$

実際に作業達成度 $\mathrm{Q}(\mathrm{q}=\mathrm{r})$ を求めるには、変 動率 $\delta$ o（作業時間のばらつき）を式(2)に代
入して求める。

$$
Q=1-\sqrt{1-\left(\frac{1}{\delta_{\infty}}\right)}
$$

さらに、達成度の 理論を応用した傾向式は、式(3)で表示する。

$$
\mathrm{t}=\mathrm{a} \mathrm{N^{ \textrm {b } }} \circledast\left(\delta_{1} \mathrm{~N}^{\mathrm{b}}\right)
$$

上式において、 $\mathrm{a}$ : 常数、 $\mathrm{b}$ : 傾向指数、 $\delta_{1}$ : 初期変動率 $(N=1) 、 b^{\prime}$; 変動指数、 $※$ : メまたは亡を示す。式(3)は、習熟における 作業時間の減少を示す項 $\left(\mathrm{a} \mathrm{N}^{\mathrm{b}}\right)$ とばらつ きの変動を示す項 $\left(\delta{ }_{1} N^{b}\right)$ から成立する。 本実験結果の解析には、式(2)、(3)を適用し た。

\section{3 、実験作業および実験条件}

本実験作業は、両手協応動作検査器を用い た。この検査器は普通旋盤を模型化した器具 である。作業方法は左手で絴送り、右手で横 送りのハンドルをそれぞれ回して遊動板に描 かれた S 字形状の図形（図 1）を固定した指 針でたどり周回させる単調作業である。作業

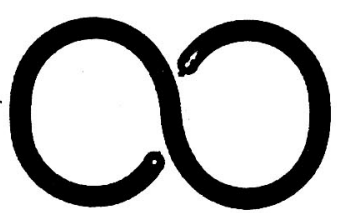

Fig.1 Track figure.

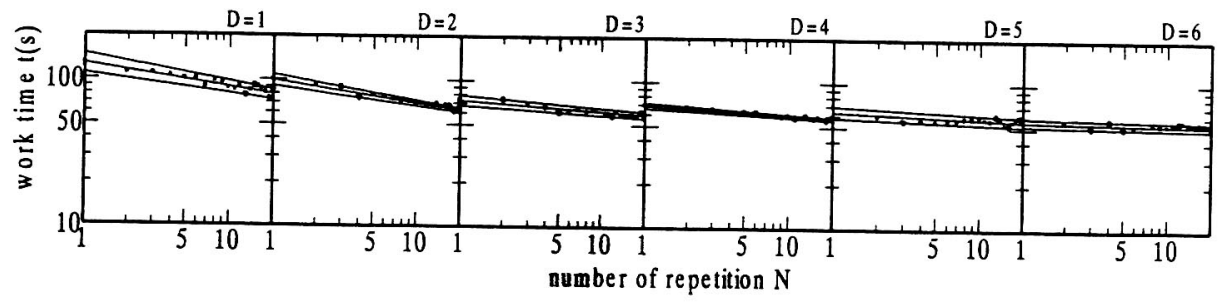

Fig.2 Analysis of professing equation in production.(Sub.No. 5) 
は辿路幅から外れないようにするため、両手 の協応性のほか、意志緊張が要求される。被 験者は男子学生 9 名、作業の難易は辿路幅を 6、4、2(mm)の 3 種類を夫々 20 回ずつ 6 日間連続して繰り返し、個別時間を測定した。

\section{4. 実験結果および考察}

\section{1 達成度手法による解析}

図 2 は、実験結果の例として被験者№. 5 の 習熟の転移状態(4mm)を式(3)によって作図し たものである。表 1 は、図 2 をもとに式(1)、(2) によって解析した結果を示す。図 2 より、作 業の経過日数に伴い、傾向指数 b の傾きは、 水平状態に転移していくことが観察できる。 さらに、表 1 から変動率 $\delta\left(\delta_{1}{ }_{1}-\delta_{20}\right)$ の值 を見ると、同様に減少している。達成度Qで 習熟の転移を評価すれば、作業 1 日目ではQ $=77.3(\%)$ であるが、作業 6 日目では $Q=93.2$ (\%)であり、習熟は増加している。

\section{2 傾向式の諸係数値間の検討}

表 3 は、解析結果の例として辿路幅 $4 \mathrm{~mm}$ における傾向式の諸特性值間の相関係数を求 めたものである。その結果、すべての諸特性 值間に有意水準 $1 \%$ で有意が認められた。辿 路幅が $2 \mathrm{~mm} 、 4 \mathrm{~mm}$ でも同様な結果となった。

\section{3 習熟転移の評価}

図 3 は、習熟の転移状態を評価するモテル 図（辿路幅 4mm）を示した。左図は達成度 の理論から求めたものであり、右図は、表 1 の変動率 $\delta$ と傾向指数 $\mathrm{b}$ の関係から回帰方程 式を示した。また表 3 は、図 3 から傾向指数 $\mathrm{b}$ を変化させ変動率 $\delta$ を算出し、この変動率 $\delta$ を式(2)に代入し、達成度 Q 転移を評価した諸係数を示す。

\section{5. おわりに}

(1)作業の難易度（辿路幅）が高くなるにし たがって習熟は低くなるが、作業日数が 4 日目以降（ $\mathrm{N}=60 ）$ では、難易度間に余 り差異が見られない。
Tab.1 Experimental results of Sub.No5

\begin{tabular}{|c|c|c|c|c|c|c|}
\hline \multirow{2}{*}{$\begin{array}{ll}\text { 作 } & \text { 業 } \\
\text { 日 } & \text { 数 }\end{array}$} & \multicolumn{4}{|c|}{$t=a N^{b} \%\left(\delta_{1} N^{b}\right)$} & \multirow{2}{*}{$\begin{array}{c}\text { 変動平 } \\
\delta \\
\end{array}$} & \multirow{2}{*}{$\begin{array}{l}\text { 達成度 } \\
\mathrm{Q}(\%)\end{array}$} \\
\hline & a & $\mathrm{b}$ & $\delta_{1}$ & $b$ & & \\
\hline 1日目 & 126.34 & -0.158 & 1.165 & -0.025 & 1.077 & 73.3 \\
\hline 2 日目 & 99.00 & -0.155 & 1.094 & -0.019 & 1.060 & 76.2 \\
\hline 3日目 & 72.91 & -0.073 & 1.083 & -0.010 & 1.029 & 83.3 \\
\hline 4日目 & 68.93 & -0.066 & 1.045 & -0.008 & 1.026 & 84.2 \\
\hline 5日目 & 63.83 & -0.045 & 1.095 & -0.007 & 1.021 & 85.8 \\
\hline 6 6月 & 55.99 & -0.021 & 1.067 & -0.002 & 1005 & \\
\hline
\end{tabular}

Tab. 2 Coefficient of correlation.( $4 \mathrm{~mm})$

\begin{tabular}{|c|c|c|c|c|}
\hline & $\begin{array}{c}\text { 作業時間 } \\
\mathrm{a}\end{array}$ & $\begin{array}{c}\text { 傾向指数 } \\
\mathrm{b}\end{array}$ & $\begin{array}{c}\text { 初期変動率 } \\
\delta_{1}\end{array}$ & $\begin{array}{c}\text { 変動指数 } \\
\mathrm{b}^{\prime}\end{array}$ \\
\hline $\mathrm{a}$ & & $-0.9632^{* *}$ & $0.8107^{* *}$ & $-0.8201^{* *}$ \\
\hline $\mathrm{b}$ & & & $-0.7400^{* *}$ & $0.7610^{* *}$ \\
\hline$\delta_{1}$ & & & & $-0.9251^{* *}$ \\
\hline $\mathrm{b}^{\prime}$ & & & & \\
\hline
\end{tabular}

(*: 有意水準 $5 \%$ ，**:有意水準 $1 \%)$

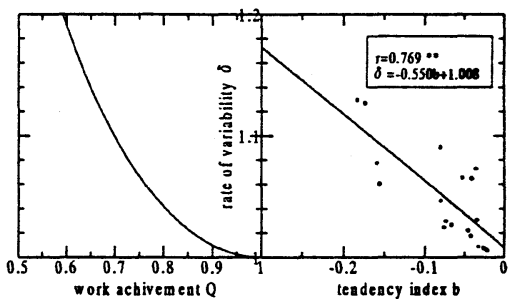

Fig.3 Appraisement of learning transfer.(4mm) Tab.3 Results of the caluculation of learning transference. $(4 \mathrm{~mm})$

\begin{tabular}{|c|c|c|c|}
\hline 日 数 & $\mathrm{b}$ & $\delta$ & $\mathrm{Q}(\%)$ \\
\hline 1 & -0.141 & 1.086 & 71.9 \\
\hline 2 & -0.115 & 1.071 & 74.2 \\
\hline 3 & -0.089 & 1.057 & 76.8 \\
\hline 4 & -0.063 & 1.043 & 79.8 \\
\hline 5 & -0.037 & 1.028 & 83.5 \\
\hline 6 & -0.010 & 1.014 & 88.3 \\
\hline
\end{tabular}

(2)傾向式の各パラメータの諸特性值間につ いて検定した結果、各難易度間において有 意が認められた。

(3)習熟の転移状態を評価できるモテル図と 諸係数を作業難易度別に提示した。

\section{参考文献}

1)福田,坂井:生産性傾向式による作業評価法, 日本経営工学会誌,32(3),188～194,1981

2)福田,大久保:達成度手法における作業習熟 の研究,人間工学,29(4),215 222,1993

3)福田,大久保:中断期間の長さが習熟に及ぼ す影響,人間工学,28(1),1～7,1992.

4)福田,大久保:作業習熟の転移と評価に関す る研究,人間工学,31(3),197 204,1995. 